\title{
TOURISM IN A SMALL TOWN: THE PEABIRU WAY IN THE STATE OF PARANÁ
}

\author{
Arléto Pereira Rochaa; \\ Washington Luiz Henrique da Silvab.
}

\begin{abstract}
This is a case study on actions to generate jobs and income through historical, adventure, cultural and ecological tourism. Its purpose is to analyze the use of the repressed tourist potential of the ancient Caminhos de Peabiru, or Peabiru Way, a walking trail in the municipality of Peabiru, through the Projeto Caminhos de Peabiru: História, Cultura e Turismo (Peabiru Way Project: History, Culture and Tourism), which was started in 2016. The name of the town of Peabiru, in northwestern Paraná, is steeped in history, as it refers to the legendary Peabiru Way. Historical studies were carried out that led to the creation of the Peabiru Way Project. Hiking trails with varying levels of difficulty were mapped out along the course of the original trails of Peabiru, and taking in sights such as waterfalls, water mines, old buildings, mountains, valleys and rivers. These trails began to attract visitors to Peabiru; initially around ten or twenty visitors on weekends, with the numbers gradually increasing to as many as eight hundred visitors on one particular weekend. Nowadays, the region hosts visitors from the USA, Japan, Spain, Australia, and all over South America. As a result, local bakeries, restaurants, hotel, and gas stations have flourished, generating an increase in local commerce, while fulfilling the initial intentions of generating jobs, income and a sense of belonging and attracting tourists and income to the town. The work is justified by the fact that the Peabiru-PR is classed as a region of poverty, due to land concentration in the hands of a few, social and economic inequality, incipient industry and trade, and stagnant services. Tourism has emerged as a sector with good prospects for the region. Methodologically, this work is characterized as qualitative study, with a literature review of books, magazines and other materials, both printed and electronic, as well as the use of measured data in the application of the Peabiru Way Project in the town of Peabiru-PR. The next step is to train official guides, working voluntarily, with the aim of reducing the number of people, but increasing increase generation and income compared to today's huge flow. Today the Peabiru Way is visited by about one thousand people a month. The Associação Caminhos de Peabiru de Artesenato e Culinária (Peabiru Way Handicrafts and Culinary Association) was created, which is marketing specific products and generating opportunities for street vendors to earn more income. It was noticed that through the work already carried out, even though it still in the initial stages, there have been positive effects on the local economy, bringing more income for the population, restaurants, bakers, and gas stations and creating direct and indirect jobs during the weekly events, particularly the walks along the Peabiru Way in the form of Acquatrekking.
\end{abstract}

\section{KEYWORDS}

History

Culture

Tourism

Peabiru Way 


\section{INTRODUCTION}

The customs and traditions of a region, and its sites of natural beauty, may seem commonplace, even banal to the people who live there. Often, things that are close at hand seem far removed from interculturality, because to see our own culture clearly, we first need to see the cultures of others.

The small town of Peabiru, in the heart of the state of Paraná, has always been blessed with an untapped source of wealth; a carefully-guarded treasure with the potential to attract tourists; an asset of unique material and immaterial richness: the walking trail known as the Caminhos de Peabiru, or Peabiru Way. The very name of the town, "Peabiru", carries a wealth of meaning. Allegorically, it could likened to a chest that sits in the living room and is full of gold coins, but is seen as just another everyday object and is never opened. Inside this chest is the Peabiru Way, an untapped and unexplored asset of great historical, cultural, and environmental and tourism potential.

Peabiru, in the state of Paraná, is located in a region with high levels of poverty, where the mainstay of the economy is agriculture, with a brutal land concentration in the hands of just a few landowners, creating a scenario of social and economic inequality, a network of services with low technical capacity, a local trade and commerce that lacks a progressive mentality, and a very small industrial park. In this context, based on figures from the United Nations (UN) which show that tourism is responsible for $7 \%$ of world exports and 10\% of global Gross Domestic Product (GDP), tourism (CAZARRÉ, 2017) we see that this segment is growing, generating jobs and income for the future of a region plagued by extreme poverty and a lack of prospects, as stated by Conte (2013, p. 414). Tourism also has the capacity to bring improvements in the balance of trade and stimulate the economy through the generation of jobs and income, as it is an "activity involving people, relationships and expectations."

As a means of attracting tourists to the town of Peabiru, generating real and effective employment and income and promoting the transfer of GDP, the historical and cultural potential of the Peabiru Way is explored.

First, starting in 2016, we conducted research using archaeological data, historical and oral sources, seeking to find out all about the Peabiru Way from the touristic and cultural perspectives, and how it is perceived by the local inhabitants. Next, we began to look at ways to promote the benefits of the trails, in order to attract tourism and boost the local culture and economy. The third phase was to attract tourists from the surrounding region, the state, the country, and even abroad, projecting its cultural, historical and touristic potential throughout Brazil.

We sought to bring economic and social benefits for the community by enhancing its history and culture and, interrelated to this, tourism, firstly with the aim of attracting tourists from a $20 \mathrm{~km}$ radius of the town of Peabiru, then $40 \mathrm{~km}$, then $100 \mathrm{~km}$, followed by state, national and international tourists, bringing economic benefits for the hotels, restaurants and food sellers, handicrafts and commerce of the town. Another objective was to strengthen the local sense of regional historical and cultural identity through the Peabiru Way, and to generate income for the local population.

This is, therefore, the essence of the analysis of the application of the Peabiru Way Project in the town of Peabiru-PR.

\section{Historical CONTEXT: THE peabiru Way}

In 1639, Father Antônio Ruiz de Montoya, a Jesuit Priest, in his work História da Conquista do Paraguai: Rio da Prata e Tucumam (History of the Conquest of Paraguay: Rio da Prata and Tucumam) mentions an eightfoot-wide trail that ran through the lands of Brazil. He does not call it the Caminho de Peabiru. The name Peabiru is probably a Portuguese pronunciation of the Guarani Indian term Peabeyú, which means "ancientcoming-and-going trail" or "trail of crushed grass".

The Peabiru Way may have originally been a transcontinental trail that connected the Pacific Ocean to the Atlantic Ocean, as a main route with numerous offshoots, characterized by a certain depth and a surface covering of grasses.

One such trail cut right across South America, a journey of around 3000 kilometers. This trail was probably joined by other, secondary trails that fed into it which, in turn, were intersected by other trails and routes, with smaller paths branching off to various indigenous settlements. According to Barros and Colavite:

Some characteristics set it apart from other trails, along its route it was approximately 08 (eight) hands wide, equivalent to 1.40 meters (one meter and forty centimeters) and 0.40 meters (forty centimeters) deep, the entire route being covered by a kind of grass that did not allow shrubs, weeds and trees to grow along its course, also preventing erosion, as it was heavily used. (BARROS AND COLAVITE, 2009, p. 87). [Author's translation]

As Barros and Colavite (2008, p. 88) point out, this main branch had two branches; "one that came from the coast of Santa Catarina and the other from the coast of São Paulo, which came together at the Paraná plateau before leading westwards, through Mato Grosso do Sul, Paraguay, Bolivia and Peru."

To travel from one place to another, the indigenous peoples would traverse the land along these trails, which were their "access routes to the interior of the continent [...], a pre-Columbian route that traversed the territory of Paraná [...] extending to the Paraná River, crossing the Tibagi, Ivaí and Piquiri rivers, and continuing on to Peru and the Pacific coast "(AGUILAR, 2002, p. 87). According to Sinclair Pozza Casemiro, the memory of the elderly inhabits of the Campo Mourão region gives the following information about Peabiru Way:

[...] there was a narrow trail, about eight to ten hands wide, and deep, where the Indians and Jesuits would pass on their to Fênix, Pitanga and the surrounding areas. It was a trail that penetrated the dense forest, inhabited by all kinds of animals and where the indige- 
nous people would walk, traversing forests and hills. A lot of pottery and lithic objects have been found, and are still found today, but now the population is more aware of the need to preserve and document these findings. (CASEMIRO, 2006, p. 59) [Author's translation].

According to Bond (2004), this trail probably led the Guarani Indians to the "Terra Sem Mal (land without evil) or "Yvy Marã e'y", which permeated their whole material and spiritual lives. In Paraguay, the trail appears with other names, such as: Peavijú, Peavirú and Tape Avirú, meaning, "Caminho Batido" (trampled or beaten trail), "Caminho Pisado" (walked trail) and "Caminho Amassado" (crushed trail). This network of trails was also the means by which the European colonists, Jesuits and pioneers arrived in the lands of Paraná. Once such traveler was the Spanish explorer Alvar Nuñez Cabeza de Vaca.

\section{Tourism Context: The Peabiru WaY}

The trails of the Peabiru Way cut through various parts of the municipality of Peabiru. Much of it has disappeared under agriculture land, but stretches of the trail can still be seen along river banks. Thus, in Peabiru, tourists can relive history and enjoy nature, by walking along stretches of ancient trails where the feet of the Guarani Indians, the Jesuits, the Portuguese and the Spanish once trod.

In view of such potential, the town promotes its Trilha Pelos Caminos de Peabiru (Peabiru Way Trail) as a tourist attraction, together with its more radical variation, the Trilha Extrema Pelos Caminhos de Peabiru (Peabiru Way Extreme Trail). The Walk can be done as part of a Town Tour, taking in a visit to the Historical Church, with its semi-Gothic architecture and architectural design brought from Germany, its beautiful stained glass windows, and sculptures by the renowned sculptor José Moser from the schools of Fine Arts in Vienna. Visitors can walk through the Central Square, with its Historic Obelisk, the Starting Point of the Peabiru Way walking routes, the City Hall, which is a listed building, and the Casa da Culture (House of culture) and finally, take a trip through Memory, History and Customs at the modern Museu Caminhos de Peabiru, which houses indigenous artifacts five thousand years old.

In the second part of the trip, tourists walk the main trail, which is $9 \mathrm{~km}$ long, a journey lasting around three and a half hours, starting at the Praça Central de Peabiru (central square). Guidance and safety are provided by the Grupo Voluntario Guardiões da Trilha da Família Caminhos de Peabiru (Volunteer Group of Guardians of the Trail of the Peabiru Way Family), comprised of nurses, firefighters, doctors, and army personnel, among other volunteers. After a twenty-minute walk, the trail passes through lush forest until it reaches Ribeirão da Lagoa, where the walk takes on the character of AcquaTrekking; alternating between dry ground and shallow and flowing water (with the option of taking a dry ground route only). The trail passes seven waterfalls in Ribeirão da Lagoa and two natural springs that provide clean drinking water. The municipality has a total of fifteen waterfalls. On the banks of the river, archaeological evidence of the indigenous travelers can be seen, as well as remnants of the colonial past, adding interest of the trail and combining ecology with environmental education and history, for the local population and visitors alike.

\section{Research Problem ANd Rele- VANCE}

The Municipality of Peabiru, which gained independent status on December 14, 1952, is located in the midwestern mesoregion of the State of Paraná, through which the ancient Peabiru Way passed. It has a population of 14,624 inhabitants, 4,944 of whom live in poverty. Despite having 1,806 students enrolled in elementary school and 587 in high school, it has an illiteracy rate of $10.42 \%$, and an HDI-M of 0.736 . Of this total , $80.81 \%$ liven in the urban area and $19.19 \%$ in the rural area. Thus, in this predominantly agricultural municipality, an antagonism has arisen, due to the increasing urban population, relegating the past to obscurity, since the historical roots of municipality and the surrounding region are mainly see in the rural events of the past and are banalized in modern urban life. (IBGE, 2015; IPARDES, 2012).

Figure 01 - Firjan Municipal Development index 2013

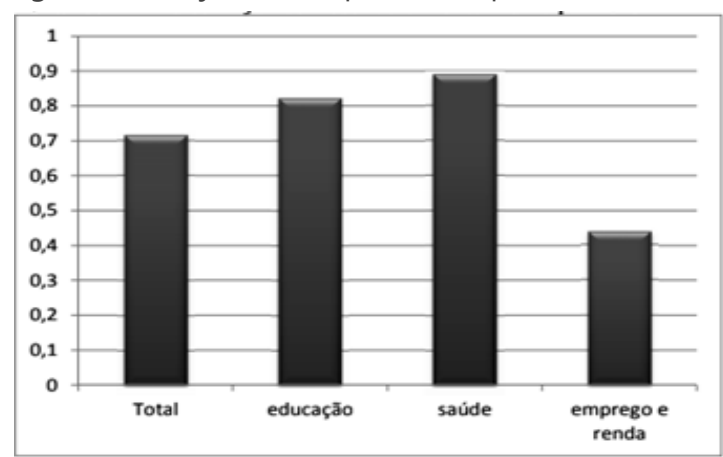

Source: Firjan (2015)

As the Firjan Municipal Development Index 2013 shows, the item employment and income has a score of just 0.4368 ("regular development"). In this context, the consolidated IFDM was 0.7158 , which is classified as "moderate development", placing Peabiru- 
PR in 204th position in the Paraná ranking (of 399 municipalities) and 1709th in the Brazil ranking. (UNESPAR, 2019).

Therefore, tourism is seen as an ideal way to take advantage of this window of opportunity, but as mentioned above, it needs public policies, such as the establishment of the Peabiru Way Project, which can take advantage of this opportunity in a number of ways. Looking at thee Ipardes Municipal Performance Index IPDM, based on its analysis under the aspects of education, health and income, Peabiru scored 0.6913 in 2015, with 0.8337 for education, 0.8418 for health, and 0.3984 for income, this latter aspect being, once again, one of the glaring weaknesses.

Figure 02 - Ipardes Municipal Development index 2015

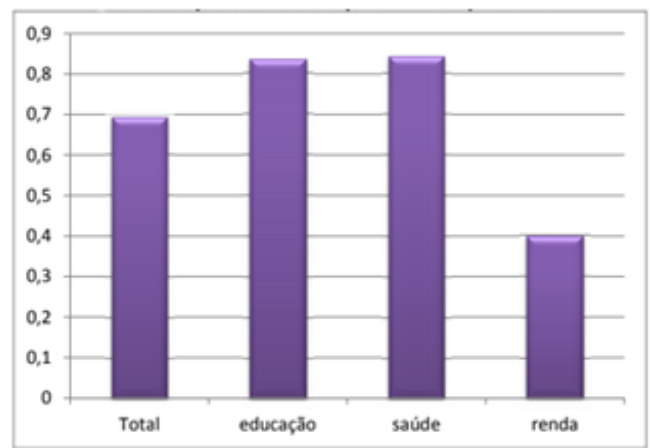

Source: Ipardes (2015)

Both indicators, as well as the IFDM and the IPDM, show improvements in education and health, but a major limitation in relation to generation of jobs and income. (UNESPAR, 2019). Hence:

Low income encourages migration to other cities in search of better working conditions. In this regard, according to Damiani (2004), migration, in most cases, involves an expropriated and impoverished population. Low income also makes the dynamics of the local economy unfeasible, as the wages obtained by the majority of the population are insufficient to promote the growth of domestic consumption. The stagnation of consumption ends up hampering small and mediumsized local businesses, which are unable to hire new employees or increase the wages of those already employed. In practice, we have a vicious cycle of stagnation that acts as a limiting factor for local development. (UNESPAR, 2019, p. 48). (Author's translation)

Thus, for a town whose economic base is agribusiness (with a brutal concentration of land, producing economic inequality), services and commerce are unable to absorb the labor and the incipient industry (the town is located between two industrial centers, Maringá and Campo Mourão) with the added prospect that for the next thirty years there will be an emptying of the cities, which would reduce the population and the transfer from the Fundo de Participação Municipal
(Municipality Social Contribution Fund) - FPM, Tourism emerges not as the "savior of the country", but as a promising alternative for generating jobs, employment and income, through the cultural, historical and economic and tourist potential that was hitherto repressed.

\section{MethOdOLOGY}

With the objective of generating jobs, employment and income through Historical, Cultural and Adventure Tourism with the historical wealth of the Peabiru Way that gives the town its name, the Peabiru Way Project is projected to run for ten years: 2017 to 2027. It rests on four non-sequential but concomitant pillars: 1 History; 2-Culture; 3-Tourism; 4-Environment. Acquatrekking-style trail routes and dry routes of about 10 $\mathrm{km}$ each were drawn up, each with around three and a half hours of trekking time.

Tourists arriving in the town buy products at the local bakeries and restaurants, and also have the option of staying at the Hotel. There is also spending at the gas station and handicrafts sellers. The walks take place every weekend, with details being posted on the social networks, the City Hall website and a specific web page. During this initial marketing stage (2017-2019) the walks are free of charge.

In 2020, the trail is expected to become professionalized, with accredited monitors and guides to carry out the work, and a charge for walkers.

The action will take place as follows

Starting date: January 2017 to December 2027.

Target Audience: First Year: targeting tourists from within a $50 \mathrm{~km}$ radius of Peabiru; Second Year: targeting tourists from within a $200 \mathrm{~km}$ radius of Peabiru; Third Year: tourists from other parts of Brazil; Fourth Year: tourists from other countries.

These objectives have been, and are based on four stages that are continually interwoven, with no definitive start or end dates.

- 1-Historical Stage: a historical survey of the town and surrounding region and its foundations, such as lithic artifacts, pottery, the presence of past civilizations in these lands, and mapping the routes taken by the trails of the Peabiru Way, and their possibilities;

- 2-Cultural Stage: to establish, in the imagination of the population, the concept of the Peabiru Way, as well as through actions in schools and society to promote an understanding of all that the Peabiru Way represents;

- 3-Environmental Stage: to evaluate environmental impacts of the use of the trails, and to promote ecological education actions aimed at protecting the $\mathrm{Ri}-$ parian Forest, natural springs, aquatic life, flora, wildlife and birds;

- 4-Stage Economic Tourism: To explore the town's 
historical, cultural and natural wealth in order to generate and attract foreign currency to the town, as part of a marketing and training plan to receive the tourist e.g., through classes in basic English for cab drivers, store cashiers, and gas station attendants.

It is notable that these four stages are concomitant and have no end, constantly intermingling, being engendered, and uninterrupted. Also as part of the project, the strengths and weaknesses of the town in terms of tourism were listed, based on what/where the tourist wants to Know, Eat, Buy and Sleep, which I term here the "3CD" formula (based on the initial letters of these items in Portuguese), and which is applied to the town of Peabiru in this current configuration. Based on these premises, the strengths and weaknesses of tourism in Peabiru-PR were conceived, as detailed in the table below.

Table 01 - Strengths and Weaknesses of Tourism in PeabiruPR

\begin{tabular}{|c|c|}
\hline HS & ES \\
\hline $\begin{array}{l}\text { Historical value of the } \\
\text { Peabiru Way. }\end{array}$ & $\begin{array}{l}\text { Lack of awareness of this } \\
\text { value among the local popu- } \\
\text { lation concerning. }\end{array}$ \\
\hline $\begin{array}{l}\text { Good nightlife, including } \\
\text { ranches with dance nights, } \\
\text { Happy Hour, a show house, } \\
\text { and a fish-and-pay lake. }\end{array}$ & $\begin{array}{l}\text { Lack of beds. Just one hotel, } \\
\text { which is in need of moderni- } \\
\text { zation. }\end{array}$ \\
\hline al attractions, with the & $\begin{array}{l}\text { Temporary crops such as } \\
\text { soybeans, corn and wheat } \\
\text { taking over riparian forests } \\
\text { and springs. }\end{array}$ \\
\hline $\begin{array}{l}\text { Acquatrekking along the } \\
\text { Peabiru Way, with seven } \\
\text { waterfalls. }\end{array}$ & $\begin{array}{l}\text { Lack of awareness among } \\
\text { farmers, of the business op- } \\
\text { portunities for rural and ad- } \\
\text { venture tourism. }\end{array}$ \\
\hline $\begin{array}{l}\text { The Historical Center and } \\
\text { Museu Caminhos de Peabiru } \\
\text { (museum). }\end{array}$ & $\begin{array}{l}\text { Lack of road signs to Peabiru } \\
\text { on the highways and a Gate- } \\
\text { way at the entrance to the } \\
\text { town. }\end{array}$ \\
\hline $\begin{array}{l}\text { The municipality has } 2 \\
\text { steakhouses, } 7 \text { restaurants, } 4 \\
\text { pizzerias, and several bars, } \\
\text { cafés and fast food outlets. }\end{array}$ & $\begin{array}{l}\text { No establishments that } \\
\text { the typical dish of bra } \\
\text { veal in wine sauce (Car } \\
\text { ao Molho de Vinho) }\end{array}$ \\
\hline $\begin{array}{l}\text { Satisfactory commercial and } \\
\text { financial network, with sev- } \\
\text { eral banks, pharmacies, and } \\
\text { gas stations. }\end{array}$ & $\begin{array}{l}\text { Handicraft industry still in } \\
\text { need of development, and ill- } \\
\text { prepared to meet the tourist } \\
\text { demand. }\end{array}$ \\
\hline Go & . \\
\hline $\begin{array}{l}\text { Proximity to Campo } \\
\text { Mourão, } 12 \mathrm{~km} \text { away, which } \\
\text { has several Colleges and } \\
\text { Universities as well as hospi- } \\
\text { tals with medium-level care }\end{array}$ & $\begin{array}{l}\text { Proximity to Campo Mourão } \\
\text { lures away investments and } \\
\text { accommodation in its hotel } \\
\text { chain. }\end{array}$ \\
\hline
\end{tabular}

Source: THE AUTHOR, 2015.
Analyzing the Strengths and Weaknesses, the Peabiru Way Project: History, Culture and Tourism was outlined. The focal point, or flagship of the project was the walks and trails, with historical, ecological, cultural and adventure background. Intense work was conducted on the walks, particularly in the aquatrekking modality, taking advantage of the abundance of nature along the trail. From there, the aim was to develop other potentials around the main focus.

\section{RESULTS}

The resulting product of this work was the creation of the "Caminhos de Peabiru" or Peabiru Way, a legendary and mystical name that attracts visitors and that, at the end of the process, is transformed into a brand linking adventure, leisure, history, culture, and environment all under one umbrella.

The low cost of the action is also worth noting, as the cost to the City Hall is almost zero, given that the natural beauty is free and the support of the trails is voluntary in the initial stage. However, investments are foreseen, so that the action can become more and more independent, seeking partnerships with the private sector, because:

We should not forget to prepare the place for citizenship, in principle and a priori, with the notion that the visitor is "one more citizen", constituting, from there, a hospitality infrastructure - signposting, visitor center, monument interpretation center, parking areas etc. - to offer complementary services and assistance in support of the development of tourism activity. (BRITO, 2019 p. 35). (Author's translation)

Therefore, the infrastructure must be prepared, through the initiative of the public authorities, and the private initiative, through short- and medium-term investments.

At present, the cultural and tourist potential of Peabiru is repressed, as the local population knows very little about the importance of these trails for the town, or even their existence. At least they do knew that the town's name comes from the Tupi-Guarani term Peya beyu, meaning "trail of crushed grass." This general lack of awareness extended to both young people and adults.

The action also includes aspects of Economic Sustainability, not only through the production and sale of handicrafts, but also through the trade for restaurants and bakeries. The inflow of visitors has led to a growth in the network of restaurants, hotels, handicrafts vendors, local commerce, and many other segments. An example occurred on January 28, 2018, a Sunday, when 600 hikers came from the cities of Paraná and São Paulo to engage in Acquatrekking, generating around twenty 
thousand reals in income for the town in one weekend. In 2017, it was estimated that the Peabiru Way was visited by about three hundred people a month, with an estimated three thousand visitors a year walking along the ecological and historical trails. It is also believed that future prospects have been stimulated through the idea of tourism, especially for young people looking for their first job. The local commerce is also gradually being stimulated by this action.

It should be emphasized that such an experience can be considered impactful and positive for the town, promoting trade and commerce in a place that had few prospects, as well as strengthening the local inhabitants' sense of belonging, prompting them to go beyond, and realize their identity and that small town tourism is possible. It is asserted that the work has a positive impact on the community, since initially there is a transfer of GDP, i.e., spending on local trade. Then there was the increase of stimulation for handicraft producers, who in addition to earning more, have benefited from the high esteem given to their work, which is sold to people from different places. And by extension, the sense of belonging of these people, the local resident, who lives in a globalized world, in a place with a face and an identity.

\section{PRACTICAL IMPLICATIONS AND CONCLUSIONS}

In a continuous act, it is observed that in these fluid times in which we live, cultural, tourist and historical projects are fundamental tools for improving the lives of the local population. This project is therefore justified by the need to create jobs and opportunities for young people and promote an economically active community. In order to qualify the workforce, their specialization is paramount. Economically, there has been an increase in the network of restaurants, hotels, handicrafts, local commerce and many other segments. An example that emphasizes this potential occurred on January 28, 2018, a Sunday, when 600 hikers came from the cities of Paraná and São Paulo to engage in Acquatrekking, generating about twenty thousand reals in income for the town on one weekend.

In 2017, it was estimated that the Peabiru Way was visited by about three hundred people a month, which means an estimated three thousand visitors a year walking along the ecological and historical trails. It is also believed that future prospects have been stimulated through the idea of tourism, especially for young people seeking their first job. The local commerce is also gradually being stimulated by this action.

It is also observed that the format of tourist attraction offered in Peabiru-PR met the desires of the so-called
"Y/Millennials" generation, i.e., those born in the 1980s and 1990s, who seek comfort combined with the enjoyment of the place and cultural experiences, immersing themselves in the place visited. For Millennials, money has a value higher than its intrinsic value; it becomes a bridge, to enable rich, unique and strong cultural experiences through tourism (CALDAS, 2019).

For this generation, as Caldas (2019) points out, "the destination itself is merely the gateway to a wider range of subjects, such as gastronomy, credit cards, or technology". Based on this premise, "Visitors remember $10 \%$ of what they hear, $30 \%$ of what they read, $50 \%$ of what they see and 90\% of what they do "(Camaredo Izquierdo and Garrido Samaniego, 2004, p. 93). Thus, it is seen that "experience-based" tourism activity, in which "the tourist appropriates from what he experiences, has high capacity to attract tourists. This statement resonates with the experience of tourists who come to trek along the trails of the Peabiru Way. (BRITO, 2019 p.37).

However, to cater for the tourists and other publics, this "experience" must also be supported by a network of restaurants, hotels, handicrafts producers and sellers, local commerce, and many other segments, which must increase in order to attract tourists from the state, the country, and abroad, bringing economic, social and historical benefits. Other works are planned, including the construction of the Teatro Caminhos de Peabiru (theater), publications on the Peabiru Way, the mapping of new trails, efforts to raise awareness among farmers of the cultural and tourist potential of the Peabiru Way for the region, and the implementation of multimedia facilities (totem displays, screens, etc.) that explain the history of the Peabiru Way using digital and technological means.

The next actions will be to provide technical training for the subject, enabling him or her to be absorbed by the Tourism, Historical, Cultural and Adventure market in the town, and enhancing the return and attraction of new tourists to the town, generating more jobs and income in a real and effective way.

Other actions will be to construct a Peabiru Way Gateway at the entrance to the town, and to promote tourist signs on the access highways, seeking to consolidate the theme as a vector of attraction and Cultural, Tourist, Human, Identity and Research development in the town of Peabiru and the region.

For the immediate future, the focus is on enabling, training and preparing citizens to attract, host, welcome, captivate tourists, and encourage them to return. At the intersection with history, the project helps to consolidate the Peabiru Way in the cultural imaginary of its people, highlighting hybridism in its Indigenous and Afro origins, derived from the contributions of European and Asian immigration, which together formed the basis of the expression of our Brazilian culture. In addition, a 
people knowing where they came from, where they live and where they are going is a people who are located and projected with greater force for the future.

\section{REFERENCES}

AGUILAR, Jurandir Coronado. Conquista Espiritual. A história da evangelização na Província do Guairá na obra de Antonio Ruiz de Montoya, 2002. (1585-1652).

BASSI, Luiz; KLEIN, João Carlos; MAFRA, Wanderley; ROCHA, Arléto. Histórias de famílias de Peabiru-PR. Campo Mourão: Kromoset, 2012

BOND, Rozana, História do caminho de Peabiru.v. 1. Aimbere: Florianópolis: 2004.

BRITO, Marcelo. A certificação de destinos patrimoniais na qualificação do turismo cultural no Brasil. Rev. do Patrimônio Histórico e Artístico Nacional. no 40. Oct. 2019

CALDAS, Manoela. Millennials: a geração das virtudes redefiniu o que é sucesso. Publicado em 21 Maio 2019. Available at https://www.terra.com.br/noticias/dino/millennials-ageracao-das-virtudes-redefiniu> Accessed on May 10, 2020

CAMAREDO IZQUIERDO, C.; GARRIDO SAMANIEGO, M. J. Marketing del patrimonio cultural. Madrid: Pirámide/Esic, 2004.

CASEMIRO, Sinclair Pozza. Compêndio sobre o caminho de Peabiru na COMCAM- Comunidade dos Municípios da região de Micro região 12 do Paraná. v. III. Campo Mourão: SOEPAL, 2006.

CAZARRÉ, Marieta. Turismo gera 5\% do PIB na União Europeia e é tema de debate. Agencia Brasil. Lisboa, 2017. Available at : $<$ http://agenciabrasil.ebc.com.br/internacional/ noticia/2017. Accessed on April 10, 2019.

COLAVITE, Ana Paula; BARROS, Miriam Barros. Geoprocessamento aplicado a estudos do Caminho de Peabiru. Revista da ANPEGE, v. 5, p. 86 - 105, 2009

CONTE, C. H. O turismo em Foz do Iguaçu (Paraná, Brasil): posicionamento diferenciado dentro da rede de cidades. Turismo \& Sociedade. Curitiba, v. 6, n. 2, p. 408-423, abril de 2013.

FIRJAN. Índice FIRJAN de Desenvolvimento Municipal - IFDM. Rio de Janeiro. Available at: <http://www.firjan.com.br/ifdm/ consulta-ao-indice/ifdm-indice-firjan-dedesenvolvimentomunicipalresultado. >. Accessed on Jan. 10, 2020.

IBGE, Diretoria de Pesquisa-DPE, Coordenação de Contas Nacionais- CONAC, Sistema de Contas Nacionais -Brasil Nota metodológica no. 9, Anos Correntes, Available at www.ibge.gov.br. Accessed on Jan. 6, 2015

INSTITUTO PARANAENSE DE DESENVOLVIMENTO ECONÔMICO E SOCIAL. Referências ambientais e socioeconômicas para o uso do território do Estado do Paraná: uma contribuição ao zoneamento ecológico- econômico - ZEE / Instituto
Paranaense de. Desenvolvimento Econômico e Social. Curitiba: IPARDES, 2012

Caderno Estatístico Município de Peabiru. Available at: < http://www.ipardes.gov.br/cadernos / MontaCadPdf1. php?Municipio $=87250 \& b t O k=0 k>$. Accessed on: Jan. 10, 2020.

ROCHA, Arléto Pereira, Os Caminhos de Peabiru: História e memória. Dissertação (Mestrado). Programa de Pós-Graduação em História. Or.: Profo. Dro. Lúcio Tadeu Mota. Universidade Estadual de Maringá. Maringá: UEM, 2017.

O Caminho de Peabiru: implicações em seu tombamento como patrimônio material e imaterial. VII Congresso Internacional de História. Universidade Estadual de Maringá, 2015.

UNESPAR. Diagnóstico de Potencialidade Local no Município De Peabiru - Paraná. Universidade Estadual Do Paraná - campus de Campo Mourão: UNESPAR, 2019. 